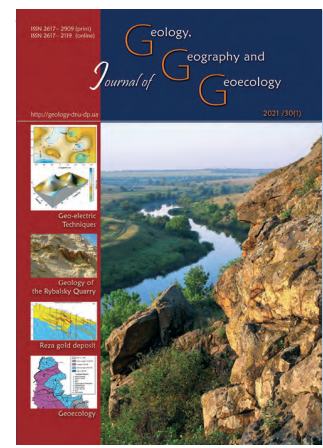

Journal of Geology,

\title{
Estimating environmental risk assessment for drinking and fisheries use (on the example of the Danube river - the city Vilkovo)
}

\author{
Maria E. Daus, Yurii V. Daus \\ Odessa National Maritime University, Odessa,Ukraine,dme2468@gmail.com
}

Received: 02.06.2020

Received in revised form: 16.06 .2020

Accepted: 09.11.2020 \begin{abstract}
region. Therefore, it was important to carry out the "Environmental Risk Assessment for
\end{abstract} Drinking and Fisheries Use (on the example of the Danube River -the city Vilkovo)". The purpose of the study was to evaluate the effectiveness of the application of the environmental risk criterion R on the basis of hydrochemical observations to verify the safety of drinking and fishery use. Analysis of environmental problems of the lower Danube River - Vilkovo; assessment of the environmental situation; calculation of water quality risk indicators according to the methodology of the Institute of Market Problems and Economic and Environmental Research of the NAS of Ukraine; establishing a link between water quality and risk is the finding of the research. It is established that the environmental situation is "critical" due to suspended substances, phenols, manganese and HCC for drinking water supply and "strained" through chromium, manganese, HCC, copper for fishery use. An assessment of the water quality by the modified Water Pollution Index (IWM) showed that the water is "moderately polluted" and "contaminated". For both types of water use, normalized aggregated pollution indices were calculated taking into account the likelihood of a risk event occurring and $\mathrm{R}$ risk indicators were determined by year. It is established that there is a close linear relationship between WSS and R. It is shown that environmental risk estimates, based on the probability of exceeding concentrations of pollutants above the MPC, reflect well the ecological status of the water.

Keywords: hydrochemical indicators, Danube, drinking and fishery use, ecological risk, maximum permissible concentration, hydrochemical pollution index, ecological situation, security

\section{Оцінювання екологічних ризиків для питного та рибогосподарського використання (на прикладі р. Дунай - м. Вилкове)}

\author{
М. Є. Даус, Ю.В. Даус
}

Одеський наиіональний морський університет, Одеса, Україна, dme2468@gmail.com

Анотація. Дунай - це джерело води для господарсько-побутових потреб населення, промисловості, сільського господарства України. Води Дунаю використовуються для питного централізованого водопостачання міст Кілія та Вилкове, також значний розвиток у регіоні має рибальство. Тому актуально було виконати «Оцінювання екологічних ризиків для питного та рибогосподарського використання (на прикладі р. Дунай - м. Вилкове)». Метою дослідження була оцінка ефективності застосування критерію екологічного ризику R на основі даних гідрохімічних спостережень для перевірки безпеки питного та рибогосподарського використання. Завдання роботи: аналіз екологічних проблем нижньої течії річки Дунай - м. Вилкове; оцінка екологічної обстановки; розрахунок показників ризиків якості води за методикою інституту проблем ринку та економіко-екологічних досліджень; встановлення зв'язків між показниками якості води та ризику. Установлено, що екологічна обстановка є «критичною» через завислі речовини, феноли, манган та ХСК для питного водопостачання та «напруженою» через хром, манган, ХСК, мідь для рибогосподарського користування. Оцінка якості води за модифікованим індексом забруднення води (ІЗВм) показала, що вода $є$ «помірно забруднена» та «забруднена». Для обох видів водокористування були розраховані нормовані агреговані індекси забруднення з урахуванням ймовірності настання ризикової події та визначені показники ризику R по роках. Установлене існування тісного лінійного зв'язку між IЗВм та R. Показано, що оцінки екологічних ризиків, розрахунки яких базуються на ймовірностях перевищення концентрацій забруднювальних речовин над ГДК, добре відображають екологічний стан води. 


\section{Introduction.}

The Danube is the largest river in Western Europe (length is $2960 \mathrm{~km}$, basin area is 817 thousand $\mathrm{km}^{2}$ ). There are 19 countries fully or partially located within the river catchment (Our Waters, 2007), and its value for 80 million people is difficult to overestimate (WWF, 2002).

A small section of the Danube River $(170 \mathrm{~km})$ from Reni to its mouth runs through the territory of Ukraine. Above the Romanian city, the Tulcea River is divided into three branches (Kiliysky, Sulinsky, and Georgievsky) and flows into the Black Sea. The most waterlogged of them is the Kiliysky sleeve $\left(129 \mathrm{~km}^{3} /\right.$ year) passing through the border area of Romania and Ukraine (Lozovitskyi, 2015).

The Danube Delta is included in the WWF (Global-200) list of the most valuable sites on Earth. In the northeastern part of it there is the Danube Biosphere Reserve, where 4300 species of fauna and flora are inhabited (WWF, 2002), dozens of which are on the verge of extinction. Delta ecosystems are a source of valuable natural resources.

On the other hand, the Danube is a source of water for domestic and industrial needs of Ukrainian population, industry and agriculture. The total water abstraction from the river within Ukraine exceeds 2 billion $\mathrm{m}^{3}$, and the number of water users is about 150 (WWF, 2002). Danube waters are used for drinking centralized water supply in the cities of Kiliya and Vilkovo (Rehionalnaprohrama; Safranov, \& Chuhai, 2017), and fisheries have significant development in the region.

Ukraine is lagging behind the developed countries in terms of average life expectancy, and high mortality is largely related to the consumption of poor drinking water. (Krainiukov, \&Yakusheva,2016). About $80 \%$ of drinking water supply in Ukraine is from surface water bodies, in which water according to hydrochemical pollution indicators has the III-IV quality class - moderately polluted and polluted water (Khvesyk,\&Yarotska, 2004). Therefore, it was important to carry out the "Environmental Risk Assessment for Drinking and Fisheries Use (on the example of the Danube River - the city Vilkovo)". The purpose of the study was to evaluate the effectiveness of the application of the environmental risk criterion $\mathrm{R}$, which was calculated on the basis of hydrochemical observations. The objective of the work was to analyze the environmental problems of the lower Danube Vilkovo; assessment of environmental conditions and water quality; calculation of water quality risk indicators according to the methodology of the Institute of Market Problems and Economic and Environmental
Research, Odessa; establishing a link between water quality and risk.

\section{Literature review.}

In the mid-twentieth century, the banks and the lakes of the river Danube were collapsed, most of the floodplain lands and islands were converted into agricultural lands, and the water regime of the lakes became regulated. Such transformations have led to a violation of the delta's ability to filter very turbid Danube water, to precipitate sediment, to trap pollutants. All these processes affect the chemical composition of the Danube Delta water.

It is established (Khilchevskyi, 2019) that at ionic runoff of the Danube into the Black Sea 70231x10 t/year, $61 \%$ of salts are carried out by the Kyliya branch, $20 \%$ by Georgievsky, and $19 \%$ by Sulinsky. And the ion runoff of the entire Danube basin is 95,2 $\mathrm{t} / \mathrm{km}$ per year.

In Ukraine, scientists from the Institute of Hydrobiology of the Academy of Sciences have been engaged in research of the lower Danube for many years. In (Harchenko et al,1993) the basic regularities of formation of hydrobiological, hydrochemical and hydrological regimes of the river are shown, the question of increasing anthropogenic influence on aquatic ecosystems of the Danube is considered. The waters of the river are moderately polluted with phenol content. The pollution of the Danube water by heavy metals (copper, zinc, chromium, manganese) is characteristic with high and very high levels (Lozovitskyi, 2015). The removal of heavy metals into the river is largely determined by the impact of point sources wastewater from municipal and industrial enterprises (Klebanov, \&Osadcha, 2012).

Researchers at the Ukrainian Hydrometeorological Research Institute have shown that the greatest amount of nitrogen in the Danube ecosystem comes from agriculture (Osadcha, \&Klebanov, 2016)and the discharge of untreated or partially treated wastewater (OurWaters, 2007), which has a significant impact on the Danube delta ecosystem. In the shelf zone, there is a «flowering» of water in the warm season, a decrease in biodiversity and fish stocks. In the early 1990s, due to the crisis in Eastern Europe and in Ukraine, the amount of nitrogen decreased, but the state of the ecosystem did not improve (Osadcha, \&Klebanov, 2016).

Specialists of the Odessa State Ecological University conducted an analysis of the main sources of anthropogenic load on natural waters of the Odessa region and an assessment of the level of surface water pollution and technogenic load on the water objects of the Odessa region by the volume of discharges of 
wastewater and pollutants (Chuhai, \&Dzhura, 2018). The quality of the surface waters of the Odessa region, including the Danube River, is characterized as «polluted». The volume of discharges of wastewater and pollutants tends to gradually decrease the level of technogenic load from 2012 to 2016.

The report (Osadchyi, 2017) states that the results of the processing of long-term hydrochemical information obtained from the observation network of the Hydrometeorological Service of Ukraine (19892015), and on the basis of ecological assessment of surface water quality, can be concluded about the beginning of stabilization and some shifts towards improvement ecological status of surface waters of Ukraine in almost all river basins, including the Danube River.

The paper (Khilchevskyi, 2019) characterizes the chemical composition of river water in the Ukrainian part of the Danube basin from the standpoint of modern hydrographic zoning of Ukraine (2016) by areas of river basins.

In order to preserve the Danube ecosystem and ensure the sustainable use of its resources, an International Commission for the Protection of the Danube River Basin was established in 1998 and a program of the Transboundary National Monitoring Network (TNMN) (Joint Danube Survey 2, 2008). In 2002, Ukraine acceded to the Convention for the Protection of the Danube River, which brings together efforts by all Danube countries to reduce pollution. Phased environmental plans and their implementation, balanced management of point and diffuse discharges, will reduce pollution of the Danube.

\section{Object, subject and research methods.}

The object of the study is the hydrochemical indices of water at the Danube River - Vilkovo compared to the limit values for drinking and fishery use. The calculations were made on the basis of data from the Danube Basin Water Management on the chemical composition of water in the Danube - Vilkovo Formation for 2009-2018.

The subject of the study is to evaluate the likelihood of significant risks of water pollution in the Danube River near the drinking water intake. Environmental risk is the likelihood of an event that is caused by the impact of economic and other activities, natural and man-made emergencies and has adverse effects on the environment (Methodical Recommendations, 2016).

Research Methods: Methods for Environmental Assessment (Muzalevskiy, \&Karlin, 2011); the method of calculations of the WFD modified (Snizhko,
2001); methodology of environmental risk assessment developed at the Institute of Market Problems and Economic and Environmental Research, Odessa (Methodical Recommendations, 2016).

\section{The results of the work and their discussion.}

Environmental assessment allows us to determine the ecological status of water bodies and to determine the cumulative effect of pollutants.

Standardizing the quality of the main components of the natural environment is to set limits for acceptable changes in their properties. Standards should be set by the response of the most sensitive organism-indicator, but practically most often set sanitary-hygienic or economically feasible standards (Muzalevskiy, \&Karlin, 2011). The environmental quality of the pollution level is considered satisfactory if two basic conditions are met: the concentrations of the pollutants $\mathrm{C}_{i}$ should be less than their maximum permissible concentration $\left(\mathrm{MPC}_{\mathrm{i}}\right)\left(\mathrm{C}_{\mathrm{i}} \leq \mathrm{MPC}_{\mathrm{i}}\right)$ and if there is a group of unidirectional substances simultaneously present in the aquatic environment, the sum of the ratio of their concentrations should be less than one $(\leq 1)$. This condition for water bodies is determined on the basis of limiting indicators of harmfulness. In comparison with the MPC values, the ecological situation is characterized by the degree of disadvantage according to the Table 1 (Muzalevskiy, \&Karlin, 2011).

Table 1. Classification of environmental conditions (Muzalevskiy, \&Karlin, 2011)

\begin{tabular}{|l|l|}
\hline $\begin{array}{l}\text { Environmental Situ- } \\
\text { ation }\end{array}$ & $\begin{array}{l}\text { Criteria for assessing the environmental } \\
\text { situation }\end{array}$ \\
\hline $\begin{array}{l}\text { Relatively satisfac- } \\
\text { tory }\end{array}$ & $\mathrm{C}_{\mathrm{i}} \leq \mathrm{MPC}_{\mathrm{i}}$, for all substances \\
\hline Tense & $\mathrm{C}_{\mathrm{i}} \approx 10 \mathrm{MPC}_{\mathrm{i}}$ \\
\hline Critical & $\mathrm{C}_{\mathrm{i}} \approx(20-30) \mathrm{MPC}_{\mathrm{i}}$ \\
\hline $\begin{array}{l}\text { Crisis (environmen- } \\
\text { tal emergency) }\end{array}$ & $\begin{array}{l}\mathrm{C}_{\mathrm{i}}>50 \mathrm{MPC} \text {, Persistent negative chang- } \\
\text { es in the natural environment. The dis- } \\
\text { appearance of certain species of animals } \\
\text { and vegetation. Threat to human health. }\end{array}$ \\
\hline $\begin{array}{l}\text { Catastrophic (envi- } \\
\text { ronmental disaster) }\end{array}$ & $\begin{array}{l}\text { Deep irreversible changes in the natural } \\
\text { environment. Imbalance, degradation of } \\
\text { flora and fauna, loss of gene pool. Poor } \\
\text { health. }\end{array}$ \\
\hline
\end{tabular}

In the first stage of the calculations the relation was established. The number of exceedances of MPC for each hydrochemical substances was determined for the entire observation period and the empirical probabilities of exceeding the MPC were calculated (Table 2, Table 3). The empirical probability of exceeding the MPC was calculated as the ratio of the 
number of cases when $\mathrm{Cu}>\mathrm{MPC}$ to the total number of cases (Venttsel, 1999). The MPC values were used for drinking water supply (DSTU 4808:2007) and fishery water use (Osadchyi et al, 2008).

Table 2. Empirical probability of exceeding the MPC (\%) chemicals in the water in the collection area for drinking water supply at Danube River Point - Vilkovo for 2009-2018

\begin{tabular}{|c|c|c|c|c|}
\hline Substance & $\begin{array}{l}\mathrm{Ci} \leq \\
\mathrm{MPC}\end{array}$ & $\begin{array}{c}\mathrm{Ci} \approx 1-10 \\
\mathrm{MPC}\end{array}$ & $\begin{array}{c}\mathrm{Ci} \approx 10 \\
-50 \mathrm{MPC}\end{array}$ & $\begin{array}{l}\mathrm{Ci}>50 \\
\mathrm{MPC}\end{array}$ \\
\hline $\begin{array}{l}\text { Suspended } \\
\text { matter }\end{array}$ & 33 & 16 & 51 & - \\
\hline $\begin{array}{l}\text { Nitrile Nitro- } \\
\text { gen }\end{array}$ & 100 & & - & - \\
\hline Iron & 99 & 1 & - & - \\
\hline HSC & 82 & 18 & - & - \\
\hline $\mathrm{BSC}_{5}$ & 97 & 3 & - & - \\
\hline $\begin{array}{l}\text { Chromium } \\
\text { (VI) }\end{array}$ & 100 & - & - & - \\
\hline Zinc & 93 & 7 & - & - \\
\hline Copper & 100 & - & - & - \\
\hline Manganese & 93 & 7 & - & - \\
\hline Phenols & 66 & 36 & - & - \\
\hline SPAR & 100 & & - & - \\
\hline
\end{tabular}

Table 3. Empirical probability of exceeding the MPC (\%) chemicals in the water for fishery use at Danube River Point Vilkovo for the years 2009-2018

\begin{tabular}{|l|c|c|c|c|}
\hline \multicolumn{1}{|c|}{ Substance } & $\begin{array}{c}\mathrm{Ci} \leq \\
\mathrm{MPC}\end{array}$ & $\begin{array}{c}\mathrm{Ci}>1-10 \\
\mathrm{MPC}\end{array}$ & $\begin{array}{c}\mathrm{Ci} \approx 10 \\
-50 \mathrm{MPC}\end{array}$ & $\begin{array}{c}\mathrm{Ci}>50 \\
\mathrm{MPC}\end{array}$ \\
\hline $\begin{array}{l}\text { Suspended } \\
\text { matter }\end{array}$ & 30 & 70 & - & - \\
\hline $\begin{array}{l}\text { Nitrile Nitro- } \\
\text { gen }\end{array}$ & 59 & 41 & - & - \\
\hline Iron & 80 & 20 & - & - \\
\hline HSC & 42 & 58 & - & - \\
\hline BSC 5 & 76 & 24 & - & - \\
\hline $\begin{array}{l}\text { Chromium } \\
\text { (VI) }\end{array}$ & 20 & 80 & - & - \\
\hline Zinc & 72 & 28 & - & - \\
\hline Copper & 52 & 47 & 1 & - \\
\hline Manganese & 29 & 67 & 4 & - \\
\hline Phenols & 61 & 39 & - & - \\
\hline SPAR & 98 & 2 & - & - \\
\hline
\end{tabular}

20 substances were investigated in total. Substances such as dissolved oxygen, ammoniacal nitrogen, nitric nitrogen, phosphates, sodium, magnesium, calcium, chlorides, sulfates and petroleum products were not observed for both uses in the study period of excess MPC.

The largest chemical pollutants for drinking water are suspended substances, phenols and chemical oxygen demand (COD). It has been found that in the
Danube river basin - Vilkovo for the period of 20092018 exceeding of the maximum permissible concentrations by 1.1 - 10 times for drinking water supply take place for phenols (36\%), manganese (7\%), HCC $(18 \%)$ and suspended solids. For suspended substances, conditions $\mathrm{C}$ up to $10 \mathrm{MPC}$ and $\mathrm{C}$ in the range of 10-50 MPC are fulfilled, exceedances of up to 10 times amounted to $16 \%$ and $10-50$ times $-51 \%$.

If not to take into account the suspended matter, it can be said that the ecological situation in the Danube - Vilkovo for water collection as drinking water supply in the studied period is in most cases «relatively satisfactory». The empirical probability of exceeding the MPC of chemicals in drinking water supply within $10-50$ times more than $50 \%$ is established only for suspended substances and is $51 \%$ (Table 2). This means that taking into account the suspended matter according to the classification of the ecological situation according to the Tables 1 and 2 in the Danube formation - Vilkovo, a «critical» ecological situation was observed.

The major pollutants for fishery use are chromium, suspended solids, manganese, chemical oxygen demand, copper, nitrite nitrogen, phenols and biological oxygen consumption for 5 days $\left(\mathrm{BSC}_{5}\right)$. In the Danube River Basin - Vilkovo, for the period of 2009-2018, the excess of MPC by $1.1-10$ times for fishery use was observed for chromium $(80 \%)$, suspended solids (70\%), manganese (67\%), HCC (58\%), copper $(47 \%)$, nitrite nitrogen $(41 \%)$, phenols $(39 \%)$, zinc $(28 \%), \mathrm{BSC}_{5}(24 \%)$, iron (20\%). This means that the environmental situation is "tense". It should also be noted that for fisheries there were single cases of exceedances of MPC 10-50 times in copper and manganese, i.e. in some periods the environmental situation worsened to «critical».

In the second stage of the calculations, an assessment of water quality was performed according to a comprehensive indicator - the Water Pollution Index (SOI) (Osadchyi, Nabyvanets, Osadcha, \&Nabyvanets, 2008). The calculation of UZV is performed on a limited number of ingredients. The modified SPI index was calculated using the following indices: dissolved oxygen, BOD5, which are mandatory, and the other four indices are the highest relative to the MPC from the list of tested substances. The SIR is calculated by the formula (Osadchyi et al, 2008, Khilchevskyi et al, 2012):

$$
W F D=\frac{1}{6} \sum_{i-1}^{n} \frac{C_{i}}{M P C_{i}}
$$

where $C_{i}$ is the average concentration of one of the six water quality indicators, and the $\mathrm{MPC}_{\mathrm{i}}$ is the 
maximum permissible concentration of each of the six water quality indicators.

According to the magnitudes of the calculated water sources, the water quality is evaluated. Water quality classes (Osadchyi et al, 2008) are distinguished as follows: I - very pure (WFD $\leq 0,2)$; II - pure (WFD 0,2-1,0); III - moderately contaminated (WFD 1,0-2,0); IV - contaminated (WFD 2.0-4.0); V - dirty (WFD 4.0-6.0); VI - very dirty (WFD 6,0-10,0); VII extremely dirty (WFD $>10)$.

The following MPCs $\left(\mathrm{mg} / \mathrm{dm}^{3}\right)$ were used to calculate the WFD modified for drinking water supply (Table 4): suspended matter - 31.5; manganese - 0.05; HSC - 15; phenols - 0.001 (DSTU 4808:2007). WFD values (Table 4) show that according to the standards for drinking water supply, water, mainly (78\%), belongs to Class IV - «contaminated». In 2012, 2015 the water quality according to the calculated index was class III - «moderately polluted».

The following MPCs $\left(\mathrm{mg} / \mathrm{dm}^{3}\right)$ were used to calculate the WFD modified for fishery purposes water objects (Table 4): manganese - 0.01; HSC - 15; chromium - 0.001; copper - 0.001 (Osadchyi et al, 2008). WFD values (Table 4) show that according to fishery standards water belongs to the II class - «moderately polluted» $-56 \%$ and to the IV class - «polluted» $-44 \%$.

In the next stage of calculations, the value of environmental risk is determined. exceeds the limit value. Beyond the maximum permissible risk is the risk of catastrophic contamination (Yurasov et al, 2011).

Environmental risks are assessed by the likelihood of adverse effects on the exploitation of natural resources. In this case, the relationship between the concentration of the substance $\mathrm{C}$ and its MPC can be included in the quantitative estimates of risk events: $\left(\mathrm{C} / \mathrm{C}_{\mathrm{MPC}}\right)$.

Identification of pollution risks is associated with activities aimed at identifying the possibility of adverse events, changes in the quality of the aquatic environment, which impair the functionality of the water body and other consequences that can lead to any damages, losses (Methodical Recommendations, 2016, Kulachok, \&Loboda, 2019).

A sufficient basis for determining the existence of a risk is the presentation of two conditions: the likelihood of occurrence of risk events and the susceptibility of the object to external influences (the possibility of receiving significant damage).

When solving the risk assessment tasks, the $\mathrm{R}$ values are calculated based on the determination of the concentration ratio of the pollutant and its MPC (Methodical Recommendations, 2016):

$$
\mathrm{R} \cong \mathrm{C}_{\mathrm{i}}>\mathrm{C}_{\mathrm{MPC}}
$$

Table 4. Modified WFD index in Danube basin - Vilkovo for 2009-2018

\begin{tabular}{|l|l|l|l|l|l|l|l|l|l|}
\hline Year & 2009 & 2010 & 2011 & 2012 & 2013 & 2014 & 2015 & 2017 & 2018 \\
\hline \multicolumn{8}{|c|}{ for drinking water supply } \\
\hline WFDm & 2.58 & 3.15 & 2.00 & 1.69 & 2.68 & 2.70 & 1.90 & 2.08 & 3.24 \\
\hline \multicolumn{8}{|c|}{ for fishery purposes } \\
\hline WFDm & 1.42 & 1.40 & 1.43 & 2.38 & 2.26 & 2.10 & 1.58 & 1.81 & 2.36 \\
\hline
\end{tabular}

Environmental risk is the likelihood of an event occurring, which is caused by the negative impact of economic and other activities, natural and man-made emergencies and has adverse effects on the environment (Loboda, \&Otchenash, 2017).

A risk event is defined as an undesirable event that can harm the environment, human health (Methodical Recommendations, 2016). Any economic or other decisions should be made in such a way that they do not exceed the limits of the harmful effects on the environment. Sometimes it is difficult to set them because the thresholds for the influence of many anthropogenic and natural factors are unknown.

The permissible environmental risk is the risk of environmental damage when the concentrations of pollutants do not exceed the MPC. The maximum risk arises when the concentration of the pollutant

$$
\begin{aligned}
& \mathrm{R}=\mathrm{C}_{\mathrm{i}} / \mathrm{C}_{\mathrm{MPCi}^{2}}>1, \\
& \mathrm{R}=\mathrm{C}_{\mathrm{MPC}} / \mathrm{C}_{\mathrm{i}}>1,
\end{aligned}
$$

where $\mathrm{C}$ is the concentration level of the $\mathrm{i}^{\text {th }}$ contaminant; $\mathrm{R}$ is a quantitative indicator of risk; SGCI is the maximum permissible concentration for the $i^{- \text {th }}$ contaminant. SGDi is assigned depending on the type of water user (DSTU 4808:2007, Osadchyietal., 2008). In identifying the risks of environmental and human health damage in the event of environmental contamination with several independent chemicals, a standardized aggregated pollution index can be used in the form (Metodychnirekomendatsii, 2016) of:

$$
, \quad \bar{R}=\sum_{i=1}^{n} \frac{C_{i}}{C_{M P C i}} \frac{N_{a i}}{N i}>1,
$$


where $\mathrm{n}$ - is the number of chemicals considered.

Given the likelihood of a risk event, the risk indicator looks like (Metodychnirekomendatsii, 2016):

$$
\bar{R}=\sum_{i=1}^{n} \frac{C_{i}}{C_{M P C i}} \frac{N_{a i}}{N i}>1,
$$

where $\mathrm{C}_{\mathrm{i}}$ is the concentration of the $\mathrm{i}^{- \text {th }}$ contaminant; $\mathrm{C}_{\mathrm{MPC}}$ is the maximum permissible concentration; $\mathrm{N}_{\mathrm{ai}}$ - the number of samples exceeding the MPC this year; $\mathrm{N}_{\mathrm{i}}$ - the total number of samples taken per a year.

As a result of the calculations, a risk indicator for drinking water supply and fishery needs was obtained for each year (Table 5).
Table 6. Statistical parameters of a number of risk indicators $\mathrm{R}$

\begin{tabular}{|c|c|c|}
\hline $\begin{array}{l}\text { The arithmetic mean } \\
\mathrm{R}_{\mathrm{am}}\end{array}$ & $\begin{array}{l}\text { Mean square devia- } \\
\text { tion } \sigma_{\mathrm{R}}\end{array}$ & $\begin{array}{l}\text { Gaussian } \\
\text { criterion }\end{array}$ \\
\hline \multicolumn{3}{|c|}{ for drinking water supply } \\
\hline 13.29 & 3.57 & 1.23 \\
\hline \multicolumn{3}{|c|}{ for fishery purposes } \\
\hline 9.83 & 2.72 & 1.16 \\
\hline
\end{tabular}

R and Risk Modified Indicators, WFD modified communication graphs were constructed and linear regression equations were obtained for drinking water supply (Fig. 1) and for fishery purposes (Fig. 2).

The analysis showed that there is a close linear relationship between the risk characteristics and the

Table 5. Risk indicator for Danube river basin - Vilkovo for 2009-2018

\begin{tabular}{|l|l|l|l|l|l|l|l|l|l|l|}
\hline Year & 2009 & 2010 & 2011 & 2012 & 2013 & 2014 & 2015 & 2017 & 2018 \\
\hline \multicolumn{8}{|c|}{ for drinking water supply } \\
\hline $\mathrm{R}$ & 14.30 & 17.60 & 11.06 & 7.57 & 14.51 & 14.71 & 10.07 & 11.33 & 18.51 \\
\hline \multicolumn{8}{|c|}{ for fishery purposes } \\
\hline $\mathrm{R}$ & 8.0 & 7.2 & 6.2 & 12.9 & 11.6 & 11.6 & 7.7 & 9.5 & 13.77 \\
\hline
\end{tabular}

When preparing management decisions related to risky events, a qualitative and quantitative assessment of possible risk situations is required. Qualitative assessment allows to evaluate possible risk areas by the following criteria: Acceptability - identification of risk acceptance; admissibility - identification of acceptable risk; criticality - identification of the zone of critical risk; inadmissibility - identification of catastrophic risk zone (Methodical Recommendations 2016).

In this technique, it is axiomatic to assume that most business results, including those that cause environmental pollution (in particular, aquatic environment), are random variables and obey a law close to normal (Gauss law). The normal law of distribution of random variables is very often used in the study of risk indicators. Checking the correspondence of the investigated random variable $\mathrm{R}$ for subordination to its normal distribution law is made on the basis of the Gaussian criterion (Venttsel, 1999):

$$
\sigma_{R} / \rho_{R}=\sqrt{\pi / 2} \approx 1,25,
$$

where $\sigma_{\mathrm{R}}$ is the root mean square deviation of the risk index $\mathrm{R}_{\mathrm{i}}$ from its arithmetic mean, and $\rho \mathrm{R}$ is the arithmetic mean deviation.

The results obtained are recorded in table 6 .

Based on the results of the calculations, it is concluded that the obtained series $\mathrm{R}$ for drinking water supply and fishery purposes are subject to the normal law of distribution. Using the obtained values of the water quality characteristics, which is estimated by the correlation coefficients $r=98$ (Fig. 1) and $r=94$ (Fig. 2 ). We see that the greater the WFD value, the greater the value of R, i.e., with the increase of pollution, the risk indicator increases. It also should be noted, that for both types of water use similar equations are obtained, the calculation of which is within the error of the original data.

According to the table of water quality classes, depending on the value of the WFD index and the obtained WFD and R correlation graphs (Fig. 1, Fig. 2), the correspondence of the water quality classes and the qualitative and quantitative characteristics of the level of damage was established (Table 7).

According to the $\mathrm{R}$ data, an empirical distribution curve of the security of this random variable was constructed (Fig. 3). Security is the probability of exceeding a given value. It is calculated by the following formula (Venttsel, 1999):

$$
P=m /(k+1),
$$

where $P$ - is the provision; $\mathrm{m}$ - is the value of $\mathrm{R}$ in the decreasing ranked row; $k$ - is the number of values in a row.

At the empirical curve, risk zones are highlighted (Fig. 3). Thus, in everyday practice, it is possible to determine the risk areas depending on the value assumed by the value of $\mathrm{R}$, as determined by hydrochemical observations. 


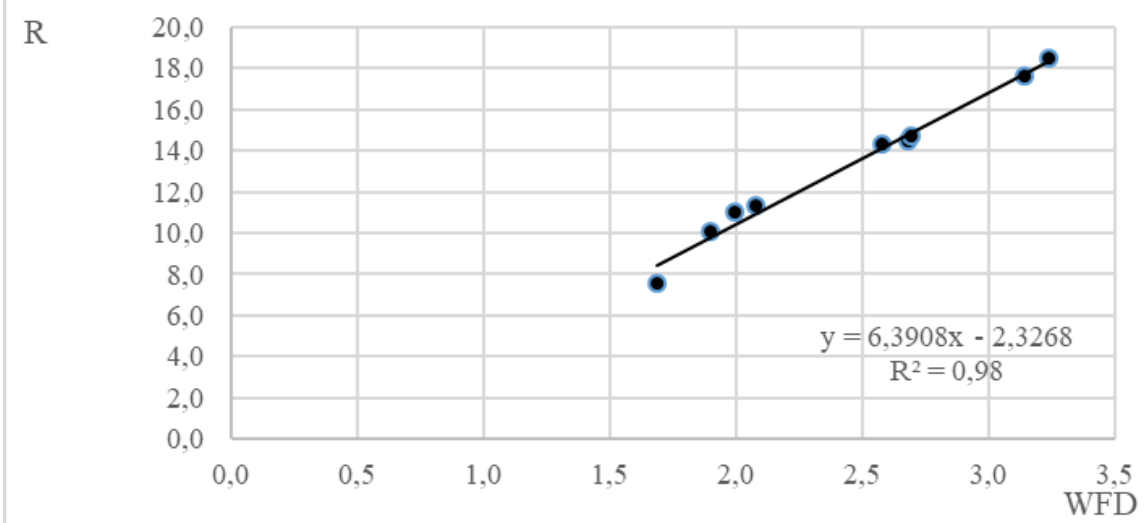

Fig. 1. Schedule of communication between R and SIC modified for drinking water supply in the Danube basin - Vilkovo, 2009-2018.

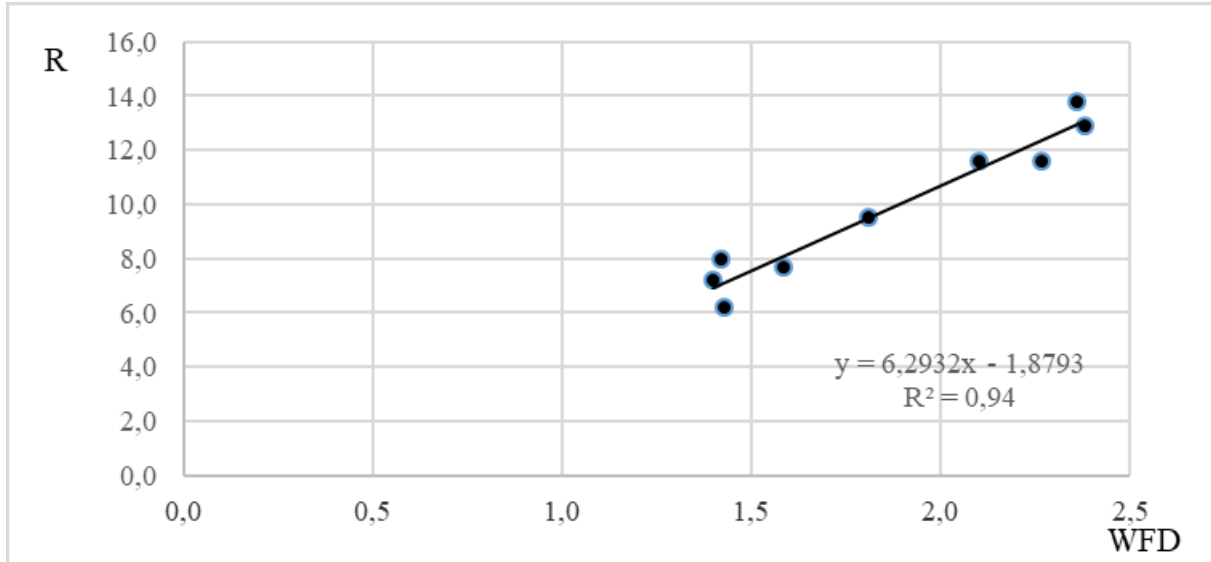

Fig. 2.Schedule for R fisheries and WFD modified for fishery purposes in the Danube Basin - Vilkovo, 2009-2018.

Table 7. Quantitative characteristics of the probability of damage

\begin{tabular}{|c|c|c|c|c|c|}
\hline WFD & $\mathrm{R}$ & Quality class of water & $\begin{array}{c}\text { Quality } \\
\text { characteristic of } \\
\text { the level of damage }\end{array}$ & $\begin{array}{l}\text { Quantitative character- } \\
\text { ization of the probabil- } \\
\text { ity of damage }\end{array}$ & Risk zone \\
\hline$<0.2$ & $<0.5$ & Very pure & Extremely low & $0.0-0.1$ & No risk \\
\hline $0.2-1.0$ & $0.5-4.0$ & Pure & Very low & $0.1-0.25$ & Acceptable \\
\hline $1.0-2.0$ & $4.0-10.5$ & Moderately contaminated & Low & $0.25-0.40$ & Affordable \\
\hline $2.0-4.0$ & $10.5-23.0$ & Contaminated & Middle & $0.40-0.60$ & \multirow{2}{*}{ Critical } \\
\hline $4.0-6.0$ & $23.0-35.0$ & Dirty & High & $0.60-0.75$ & \\
\hline $6.0-10.0$ & $35.0-61.0$ & Very dirty & Very high & $0.75-0.90$ & Catastrophe \\
\hline$>10.0$ & $>61.0$ & Extremely dirty & Extremely high & $0.90-1.0$ & $\begin{array}{l}\text { Irreversibility } \\
\text { of the loss of an } \\
\text { object }\end{array}$ \\
\hline
\end{tabular}

\section{Conclusions.}

- The main pollutants in water of the Danube River Basin - Vilkovo for the years 2009-2018 are suspended substances, phenols, manganese and HCC that limit drinking water supply. For suspended substances, the empirical probability of exceeding the MPC of drinking water supply by 10-50 times more than $50 \%$ is established, therefore the "crisis" ecological situation is determined. For fishery use, the main pollutants in the Danube River Basin - Vilkovo for the 2009-2018 years are chromium, suspended matter, manganese, HCC, copper, and nitrite nitrogen. The environmental situation is "tense".

- Assessment of water quality according to the modified WFD showed that according to the standards for drinking water supply, water was mainly (78\%), grade IV quality - «contaminated»; According to fishery standards, water was classified 


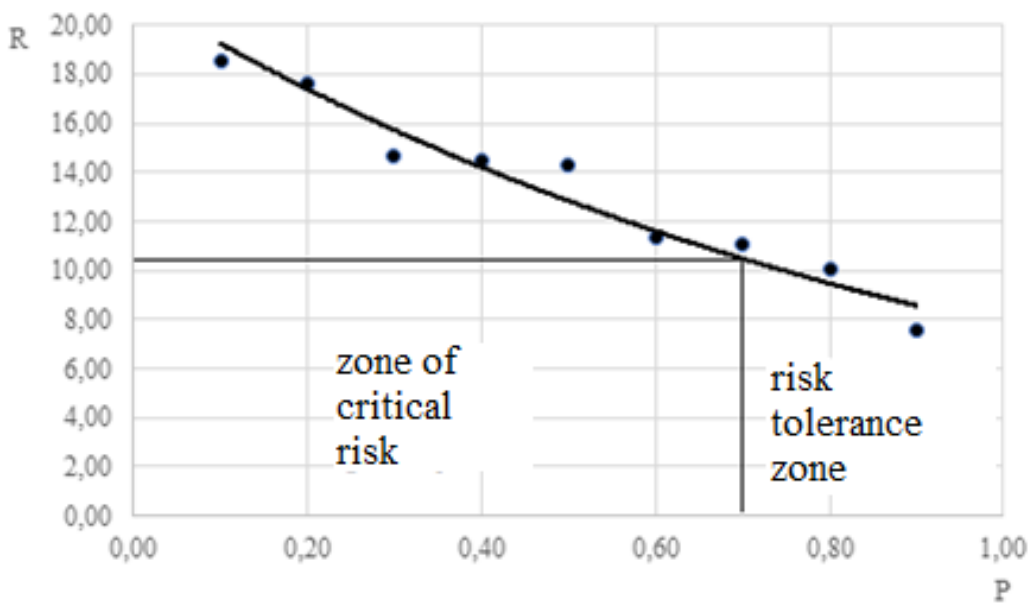

Fig. 3.Empirical curve of distribution of security of risk indicator R and selected risk zones

as class III - «moderately polluted» $(56 \%)$ and class IV - «polluted» (44\%).

- Normalized aggregated pollution indices were calculated for both types of water use, taking into account the probability of occurrence of a risk event and the risk indicators $\mathrm{R}$ for years were determined. Using the Gaussian criterion, it was confirmed that the calculated risk index R obeys the normal law of distribution.

- It is established that there is a close linear connection between WFD modified and R for drinking and fishery use $(r=99, r=97)$. It is shown that the index R increases with the increase of the WFD.

- The correspondence of differentiation of the scale of water quality and qualitative and quantitative characteristics of the level of damage was established when using the risk indicator $\mathrm{R}$.

- Risk zones have been established based on the construction of an empirical curve for the distribution of risk indicators. The resulting curve can be used to determine the risk zone depending on the value of the environmental risk indicator $\mathrm{R}$.

- For drinking water use, $\mathrm{R}$ varied from 7.57 to 18.51, for fishery needs from 6.2 to 13.77. Therefore, one empirical curve for the distribution of the security of the risk indicator $\mathrm{R}$ was constructed and the risk zones were identified: the «tolerable risk zone» (WFD varies within 1.0-2.0) and the «critical risk zone» (WFD 2.0-4.0).

- It is shown that environmental risk assessments, based on the probability of exceeding concentrations of pollutants above the MPC, reflect well the ecological status of water and can be used to test the safety of drinking and fishery use.

\section{References}

Chuhai, A. V., \&Dzhura, O. S., 2018. Otsinka rivnia zabrudnennia I tekhnohennoho navantazhennia na poverkhnevi vody Odeskoi oblasti [Assessment of pollution level and technogenic load on surface waters of Odessa region]. Ekolohichna bezpeka, № 2 (26), 59-63. (in Ukrainian).

DSTU 4808:2007. Dzherela tsentralizovanoho pytnoho vodopostachannia. Hihiienichni ta ekolohichni vymohy shchodo yakosti vody I pravyla vybyrannia. [DSTU 7525: 2014 Sources of centralized drinking water supply. Hygienic and environmental requirements for water quality and selection rules]. Retrieved from: <http://document.ua/dzherelacentralizovanogo-pitnogo-vodopostachannja_gigienic-std3067.html $>$ [Accessed 24 December 2019]. (in Ukrainian).

Harchenko, T.A., Timchenko, V.M.,\&Koval'chuk, A.A.,1993.Gidrojekologija ukrainskogo uchastka Dunaja i sopredel'nyh vodoemov. [Hydroecology of the Ukrainian section of the Danube and adjacent bodies of water]. Kiev: Naukovadumka. (in Ukrainian).

Joint Danube Survey 2. 2008. Final Scientific Report, 154168.

Khilchevskyi, V.K., Osadchyi, V.I., \&Kurylo, S.M., 2012. Osnovy hidrokhimii [Fundamentals of hydrochemistry]: pidruch. Kyiv: Nika-Tsentr. (in Ukrainian).

Khvesyk, M.A., \&Yarotska, O.V., 2004. Upravlinnia vodnymy resursamy Ukrainy. [Water Resources Management of Ukraine]. Kyiv: RVPS NAN Ukrainy. (in Ukrainian).

Klebanov, D.O., \&Osadcha, N.M., 2012. Otsinka vynosu spoluk vazhkykh metaliv vodamy r. Dunai u su- 
chasnyi period [Estimation of removal of heavy metal compounds by the Danube waters in the modern period]. Nauk. pratsiUkrNDHMI, issue 263, 131-151. (in Ukrainian).

Krainiukov, O. M., \&Yakusheva, A. V.,2016.Otsinka ryzyku dlia zdorovia liudei, obumovlenoho vykorystanniam zabrudnenykh naftoproduktamy pytnykh vod za dopomohoiu metodyky RAIS (US-EPA). [Human health risk assessment of the use of contaminated drinking water with the use of RAIS (US-EPA)] Liudyna ta dovkillia. Problemy neoekolohii, № 3-4 (26), 46-51. (in Ukrainian).

Kulachok, K.V., \&Loboda, N.S., 2019. Yakisne ta kilkisne otsiniuvannia ekolohichnykh ryzykiv u nyzhnii techii Dnistra (smt Biliaivka) / Materialy naukopraktychnoi konferentsii vseukrainskoho konkursu studentskykh naukovykh robit za spetsialnistiu «Ekolohiia» (20-22 bereznia 2019 roku). Poltava: PoltNTU, P. 29. (in Ukrainian).

Loboda, N.S., \&Otchenash, N.D., 2017. Pidzemnivody, yikh zabrudnennia ta vplyv na navkolyshnie seredovyshche [Groundwater, their pollution and environmental impact]: navchalnyi posibnyk. Kh.: FOP Panov A.M. (in Ukrainian).

Lozovitskyi, P.S., 2015. Spetsyfichni rechovyny toksychnoi dii u vodirichky Dunai. [Specific toxic substances in the Danube River water]. Ekolohichni nauky, № 6, 21-34. (in Ukrainian).

Metodychni rekomendatsii shchodo otsinky y movirnosti ryzykovykh podii $\mathrm{v}$ naslidok zabrudnennia vodnykh obiektiv ta gruntiv ukrainskoi chastyny Nyzhnodunaiskoho rehionu. 2016. [Methodical recommendations for assessing the probability of risk events due to pollution of water bodies and soils of the Ukrainian part of the Lower Danube region]. Odesa: FOP Shylov M. V.

MistoVylkove. Retrieved from: <https://uk.wikipedia. org/wiki/\%D0\%92\%D0\%B8\%D0\%BB\%D0\% BA $\%$ D0\%BE $\%$ D0\%B2\%D0\%B5> [Accessed 24 December 2019]. (in Ukrainian).

Muzalevskiy, A. A., \&Karlin, L. N., 2011. Ekologicheskieriski: teoriyaipraktika [Environmental risks: theory and practice]. Sankt Peterburg: RGGMU, VVM. (in Russian).

OurWaters: Joining Hands Across Borders: First Assessment of Transboundary Rivers, Lakes and Croundwaters, 2007. NewYork and Geneva. Retrieved from: http://www.unece.org/env/water.

Osadcha, N.N., \&Klebanov D.A., 2016. Otsenka vynosa byohennykh elementov s vodosbornoi ploshchady Dunaia v sovremennyi peryod (1989-2012 hh.), osnovnye factory eho formyrovanyia y puty rehulyrovanyia [Assessment of the removal of nutrients from the Danube catchment area in the modern period, the main factors of its formation and regulation]. Nauk. Pratsi Ukr NDHMI, issue 268. 58-66. (in Russian).

Osadchyi, V.I., 2017. Resursy ta yakist poverkhnevykh vod Ukrainy $\mathrm{v}$ umovakh antropohennoho navantazhennia ta klimatychnykh zmin [Resources and quality of Ukraine's surface water under conditions of anthropogenic loading and climate change]. Visnyk NAN Ukrainy, 8, 29-45. (in Ukrainian).

Osadchyi, V.I., Nabyvanets, B.I., Osadcha, N.M. \& Nabyvanets, Yu.B., 2008. Hidrokhimichnyi dovidnyk. Poverkhnevi vody Ukrainy. Hidrokhimichni rozrakhunky. Metody analizu [Hydrochemical reference book. Surface waters of Ukraine. Hydrochemical calculations. Methods of analysis]. Kyiv: Nika-Tsentr. (in Ukrainian).

Otsinka ryzykiv dlia zdorovialiudyny ta navkolyshnoho seredovyshcha vid dzherel zabrudnennia gruntu ta vod: zvit informatsiino ikonferentsii v ramkakh proektu «Inventaryzatsiia, otsinka ta zmenshennia vplyvu antropohennykh dzherel zabrudnennia v Nyzhnodunaiskomu rehioni Ukrainy, Rumuniii Respubliky Moldova (MISETCCODE 995)». 2016. Za red. B.V Burkynskoho, O.Ie. Rubelia; NAN Ukrainy, In-t probl. rynku ta ekon.-ekol. doslidzh. Odesa. (in Ukrainian).

Rehionalna prohrama «Pytna voda Odeskoi oblasti» na 2010-2013 roky i period do 2020 roku». [Regional program "Drinking water of Odessa region" for 2010-2013 and the period until 2020] Retrieved from: <http://oblrada.odessa.gov.ua/wp-content/ uploads/1170-V.pdf> [Accessed 24 December 2019]. (in Ukrainian).

Safranov, T.A. \& Chuhai, A.V., 2017. Stan I yakist pryrodnoho seredovyshcha pryberezhnoi zony Pivnichno-Zakhidnoho Prychornomoria [The state and quality of the natural environment of the coastal zone of the Northwest Black Sea]. Kharkiv: FOP Panov A.M. (in Ukrainian).

Snizhko, S. I., 2001. Otsinka ta prohnozuvannia yakosti pryrodnykh vod [Assessment and forecasting of natural water quality]. Pidruchnyk- K.: NikaTsentr, (in Ukrainian).

Venttsel, E.S., 1999. Teoriya veroyatnostey [Probability theory]. 6rd ed. Moskva: Vysshaja shkola. (in Russian).

WWF, Vision of the Danube Delta,2002. - Vena - Odessa. Retrieved from: <https://danube.odessa.gov.ua/ wp-content/uploads/2019/02/danube delta vision_rus.pdf $>$ [Accessed 24 December 2019].

Yurasov, S.M., Safranov, T.A., \&Chuhai, A.V., 2011. Otsinka yakosti pryrodnykh vod [Assessment of natural water quality]: Navchalnyi posibnyk. Odesa. (in Ukrainian). 